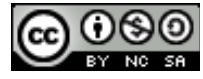

https://doi.org/10.31743/abmk.13205

KS. KRZYSZTOF DOROSZ SJ* - WARSZAWA

KATARZYNA TRZCIŃSKA** - WARSZAWA

\title{
JEZUICI W OBIEKTYWIE. ZBIORY FOTOGRAFICZNE ARCHIWUM PROWINCJI WIELKOPOLSKO-MAZOWIECKIEJ TOWARZYSTWA JEZUSOWEGO
}

\section{Streszczenie}

Artykuł ma na celu przedstawienie zbiorów fotograficznych znajdujących się w posiadaniu Archiwum Prowincji Wielkopolsko-Mazowieckiej Towarzystwa Jezusowego. W ostatnich latach daje się zaobserwować wzrost zainteresowania zdjęciami zarówno wśród zawodowych historyków, jak i pasjonatów przeszłości. Zdjęcia w posiadaniu Archiwum obejmują okres od początku XX wieku po współczesność. W pierwszej kolejności uwiecznieni na nich zostali przede wszystkim ludzie: jezuici wszystkich szczebli hierarchii zakonnej, ważne postaci historii Polski i Kościoła powszechnego, a także osoby świeckie związane z jezuitami. Następnie można wyodrębnić zdjęcia budynków należących do jezuitów i prowadzonych przez nich dzieł oraz dokumentację ważnych wydarzeń w historii Polski. Artykuł zamyka omówienie zdjęć jezuitów - pasjonatów fotografii.

Słowa kluczowe: jezuici polscy; Prowincja Wielkopolsko-Mazowiecka Towarzystwa Jezusowego; fotografia archiwalna

* Ks. Krzysztof Dorosz SJ - dr literaturoznawstwa, dyrektor Archiwum Prowincji Wielkopolsko-Mazowieckiej Towarzystwa Jezusowego

e-mail: k.dorosz@jezuici.pl

https://orcid.org/0000-0003-4483-4608

** Katarzyna Trzcińska - mgr archeologii, Instytut Kultur Śródziemnomorskich i Orientalnych, Polska Akademia Nauk

e-mail:kh.trzcinska@wp.pl

https://orcid.org/0000-0002-4244-1758 


\section{Wprowadzenie}

Archiwum Prowincji Wielkopolsko-Mazowieckiej Towarzystwa Jezusowego ${ }^{1}$ jest integralną częścią Kurii Prowincji Wielkopolsko-Mazowieckiej Towarzystwa Jezusowego. Ta jezuicka jednostka administracyjna powstała w $1926 \mathrm{r}$. w wyniku podziału dynamicznie rozwijającej się po 1918 r. Prowincji Polskiej (następczyni Prowincji Galicyjskiej, funkcjonującej w latach 1820-1918 na terenie zaboru austriackiego). Decyzją generała zakonu, o. Włodzimierza Ledóchowskiego, utworzono w odrodzonej Polsce dwie odrębne prowincje: Wielkopolsko-Mazowiecką i Małopolską (od 1975 r. pod nazwą Prowincja Polski Południowej TJ)2. W latach międzywojennych siedzibą pierwszej z wyróżnionych kurii był dom zakonny przy ul. Świętojańskiej $12 \mathrm{w}$ Warszawie ${ }^{3}$. Tam też zostało zlokalizowane archiwum kurialne, którym zajmowali się głównie socjuszowie prowincjała (oo. Antoni Czenczek, Feliks Lasoń, Marian Nowak, Edmund Elter $)^{4}$. Kuria Prowincjalna działała w tym miejscu do września 1944 r. Podczas powstania warszawskiego zarówno rezydencja, jak i kościół Najświętszej Maryi Panny Łaskawej zostały całkowicie zburzone. Dnia 27 sierpnia 1944 r. spłonęło też główne archiwum prowincji, a tym samym duża część archiwaliów została bezpowrotnie zniszczo$\mathrm{na}^{5}$. We wczesnym okresie powojennym tymczasową siedzibą prowincjała stał się wybudowany krótko przed wojną Dom Pisarzy przy ul. Rakowieckiej 61, miejsce masakry 2 sierpnia $1944 \mathrm{r}^{6}{ }^{6}$ Tam też znalazło się podręczne archiwum kurii, a zajmowali się nim: o. Włodzimierz Mielnik, o. Władysław Ziomkowski, o. Wincenty Orsaczek, o. Józef Wieteska. Po odbudowie rezydencji i kościoła przy ul. Świętojańskiej w Warszawie w 1955 r. powróciła tu kuria prowincji wraz z ocalałą częścią archiwum, którym opiekowali się kolejni socjuszowie. Powoli odbudowywano zasób archiwum. W 1982 r. przeniesiono je do nowej siedziby kurii przy ul. Narbutta na warszawskim Mokotowie, gdzie znajduje się do dziś7. Po modernizacji i rozszerzeniu bazy lokalowej w $2000 \mathrm{r}$. archiwum zostało otwar-

${ }^{1}$ Dalej: Archiwum PWM lub Archiwum.

${ }^{2}$ Zob. Dekret generalski z dnia 31 lipca 1926 roku, w: 50 lat Prowincji Wielkopolsko-Mazowieckiej Towarzystwa Jezusowego (1926-1976). Sylwetki i wspomnienia, Rzym 1976, s. 7-8; Prowincja zakonna, w: Encyklopedia wiedzy o jezuitach na ziemiach Polski i Litwy 1564-1995, red. L. Grzebień, Kraków 2004, s. 540-544 (dalej: EWJ).

${ }^{3}$ Zob. Warszawa-Rezydencja NMP Laskawej, w: EWJ, s. 722-723.

${ }^{4}$ Socjusz prowincjała (dosł. towarzysz) to w zakonie jezuitów nazwa urzędu sekretarza i doradcy przełożonego prowincji, w wyjątkowych sytuacjach jego zastępcy, odpowiedzialnego także za kancelarię i archiwum; zob. Socjusz, w: J. Kołacz, Słownik języka i kultury jezuitów polskich, Kraków 2006, s. 254-255.

5 Zob. Historia domów Prowincji Wielkopolsko-Mazowieckiej Towarzystwa Jezusowego, cz. 2: (1939-1945), oprac. T. Pronobis, Archiwum PWM, Warszawa 2002, s. 45-46, [kmps]; Catalogus Provinciae Poloniae Maioris et Mazoviae Societatis Iesu 1939-1945: Odpowiedzi na kwestionariusz do dzieła „Kościót katolicki a okupacja niemiecka 1939-1945”, Archiwum PWM, Warszawa 1948, s. 18, [mps].

${ }^{6}$ Zob. Warszawa, ul. Rakowiecka 61, w: EWJ, s. 723.

${ }^{7}$ Zob. Warszawa, ul. Narbutta 21, w: EWJ, s. 723-724. 
te dla badaczy spoza zakonu i obecnie pełni rolę ośrodka badań nad historią jezuitów.

Archiwum gromadzi materiały związane z funkcjonowaniem zakonu, datujące się na okres od końca XIX wieku po dzień dzisiejszy. W zbiorze zostały wydzielone dwa zespoły. Pierwszy, Zespół personalny, to spuścizna zmarłych jezuitów, na którą składają się dokumenty, zdjęcia, korespondencja, teksty na tematy religijne i nie tylko, notatki oraz wszelkiego rodzaju pamiątki (m.in. odznaczenia, medale, dyplomy). Drugi zespół, Zespół placówki, to dokumenty związane z działalnością domów zakonnych, dotyczące przede wszystkim działalności placówek jezuickich z terenu prowincji (zarówno czynnych, jak i historycznych), ale również dzieł jezuickich - stowarzyszeń, szkół, misji oraz działalności medialnej, publicystycznej, misjonarskiej i edukacyjnej. W skład zbioru wchodzą m.in. czasopisma, prace dyplomowe, dokumenty i fotografie związane z działalnością poszczególnych placówek, a także księgi ogłoszeń duszpasterskich, niedzielnych i świątecznych, zdjęcia, dokumentacja działalności wspólnot lokalnych czy biuletyny parafialne.

Archiwum nie posiada osobnego repozytorium fotografii, przyjmujemy zasadę, że pozostają wraz z materiałami, z którymi do nas trafiły, aby nie pozbawiać ich kontekstu. W większości mamy do czynienia ze zdjęciami analogowymi (pozytywy wywołane, negatywy na kliszach i płytkach szklanych), jednak w miarę spływania bardziej współczesnych materiałów rośnie nam zbiór fotografii cyfrowej.

Zdjęcia wywołane przechowujemy w kopertach (w przypadku mniejszych zbiorów) bądź w pudełkach bezkwasowych, płyty CD w kopertach lub w pudełkach plastikowych, zaś skany i fotografie cyfrowe na osobnym dysku zewnętrznym. Zbiór jest bardzo dobrze zachowany, do najczęstszych uszkodzeń należą zagięcia fotografii oraz pęknięcia szklanych negatywów.

Zdjęcia znajdujące się w zbiorach Archiwum można podzielić na kilka głównych kategorii: zdjęcia osób (zarówno członków Towarzystwa Jezusowego, jak i fotografie osób nienależących do zakonu - duchownych i świeckich), zdjęcia dzieł i placówek jezuickich (istniejących i historycznych), dokumentację wydarzeń historycznych i kościelnych oraz zdjęcia autorstwa jezuitów fotografików. Oczywiście wiele fotografii można zakwalifikować do więcej niż jednej kategorii.

\section{Zdjęcia osób}

Wśród zdjęć jezuitów znajdują się fotografie zarówno członków Prowincji Wielkopolsko-Mazowieckiej, jak i zakonników należących do innych prowincji (np. bratniej jezuickiej Prowincji Polski Południowej). Przy różnych okazjach uwieczniani bywali zakonnicy wszystkich stopni hierarchii zakonnej - od przełożonych generalnych (choćby generałowie W. Ledóchowski, Pedro Arrupe, Peter Hans Kolvenbach), przez prowincjałów i superiorów domów, po scholastyków i nowicjuszy.

Zbiór ten przedstawia znaczną wartość historyczną. Obserwujemy duże zainteresowanie nim tak profesjonalnych badaczy, wydawców, dokumentalistów i filmowców, jak i osób prywatnych. Zdjęcia ze zbiorów Archiwum są chętnie wykorzystywane w publikacjach naukowych, czego przykładem może być niedawno 
wydana publikacja Bartłomieja Noszczaka Za klasztorna furtą. Migawki z życia i działalności jezuitów w Warszawie (1945-1956), w której zostały wykorzystane liczne zdjęcia jezuitów pracujących w Warszawie w latach 40. i 50. XX wieku8.

Wielu kapłanów Towarzystwa Jezusowego zaznaczyło się w historii Kościoła oraz w dziejach Polski. Taką postacią był kapelan powstania warszawskiego, po wojnie znany pisarz i publicysta, o. Józef Warszawski ${ }^{9}$. Do tego grona należy także kapelan podziemia niepodległościowego o. Władysław Gurgacz ${ }^{10}$, skazany na karę śmierci w 1949 r., którego szczątki zostały odnalezione podczas prac ekshumacyjnych w październiku $2018 \mathrm{r}^{11}$ i ponownie pochowane $\mathrm{z}$ honorami 14 września 2021 r. na Cmentarzu Rakowickim w Krakowie ${ }^{12}$. Również można tu wskazać kard. Adama Kozłowieckiego, więźnia Auschwitz i Dachau, a po wojnie misjonarza w Zambii ${ }^{13}$.

${ }^{8}$ B. Noszczak, Za klasztorna furtą. Migawki z życia i działalności jezuitów w Warszawie (19451956), Warszawa 2020.

9 Józef Warszawski SJ (1903-1997), kapelan zgrupowania „Radosław”, pseud. Ojciec Paweł. Jako delegat komendy zgrupowania „Radosław” do Komendy Głównej Armii Krajowej forsował plan ewakuacji AK do Kampinosu. Ostatniego dnia walk na Czerniakowie uratował życie niemal 120 osób, uzyskując dla nich od niemieckiego dowództwa status jeńców wojennych. Po wojnie był znanym pisarzem i publicystą, współpracował z ruchem sodalicyjnym. W latach 1951-1957 kierował Sekcją Polską Radia Watykańskiego; zob. Warszawski Józef, w: EWJ, s. 724.

${ }^{10}$ Władysław Gurgacz SJ (1914-1949), kapelan Polskiej Podziemnej Armii Niepodległościowców. W 1949 r. został aresztowany i skazany na karę śmierci przez Wojskowy Sąd Rejonowy w Krakowie. Wyrok wykonano 14 września 1949 r. w krakowskim więzieniu na Montelupich; zob. D. Golik, F. Musiał, Władysław Gurgacz. Jezuita wyklęty, Kraków 2014. W 2020 r. przy współpracy Instytutu Pamięci Narodowej i Prowincji Wielkopolsko-Mazowieckiej Towarzystwa Jezusowego został wydany jego dziennik duchowy (W. Gurgacz SJ, Refleksje, oprac. M. Chodyko przy współpracy K. Dorosza SJ, Warszawa 2020).

${ }^{11}$ Zob. https://jezuici.p1/2019/12/zidentyfikowano-szczatki-o-wladyslawa-gurgacza-sj (dostęp: 01.12.2021). Warto dodać, że ekshumacja doprowadziła do zidentyfikowania prochów i właściwego określenia miejsca pochówku o. W. Gurgacza, innego niż wcześniej sądzono. Ciała trzech zamordowanych w więzieniu na Montelupich partyzantów Polskiej Podziemnej Armii Niepodległościowców (o. Władysława Gurgacza, Stefana Balickiego i Stanisława Szajny) złożono w dwóch nieoznaczonych grobach wojskowej części Cmentarza Rakowickiego, a także w drewnianych skrzyniach bez zewnętrznej adnotacji. W ewidencji cmentarnej błędnie przypisano ofiary do grobów. Jak się okazało, byli pochowani inaczej, w innej konfiguracji, niż wcześniej sądzono; zob. F. Musiał, Ks. Władysław Gurgacz „Sem”, Kraków 2020, s. 27-29.

12 Zob. https://diecezja.pl/aktualnosci/ks-wladyslaw-gurgacz-spoczal-na-cmentarzu-rakowickim-w-krakowie/ (dostęp: 01.12.2021).

${ }^{13}$ Adam Kozłowiecki SJ (1911-2007), misjonarz, arcybiskup, kardynał prezbiter. W latach 1933-1934 był wychowawcą młodzieży w Konwikcie Zakładu Naukowo-Wychowawczego św. Józefa w Chyrowie. Po aresztowaniu przez gestapo 10 listopada 1939 r. trafił wraz z grupą jezuitów do krakowskiego więzienia na Montelupich, potem do Wiśnicza, skąd został przewieziony do obozu koncentracyjnego w Auschwitz, a następnie do Dachau. Dnia 29 kwietnia 1945 r. uczestniczył w wyzwoleniu obozu przez wojska amerykańskie. Po wojnie wyjechał na misję jezuicką do Zambii. W 1959 r. został pierwszym arcybiskupem metropolitą Lusaki. Funkcję tę pełnił do 1969 r. Stanowczo opowiadał się za równouprawnieniem ras. Wydał m.in. Ucisk i strapienie. Pamiętnik więźnia 1939-1945 (Kraków 1995) oraz Moja Afryka, moje Chingombe. Dzieje misjonarza opisane w listach 


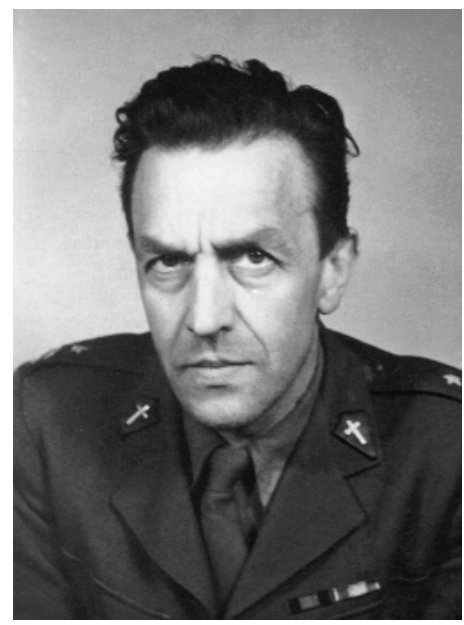

Il. 1. Józef Warszawski SJ w mundurze brytyjskim pełniący funkcję kapelana w brytyjskiej strefie okupacyjnej

w Niemczech (1947-1948).

Zbiory Archiwum PWM, Warszawa

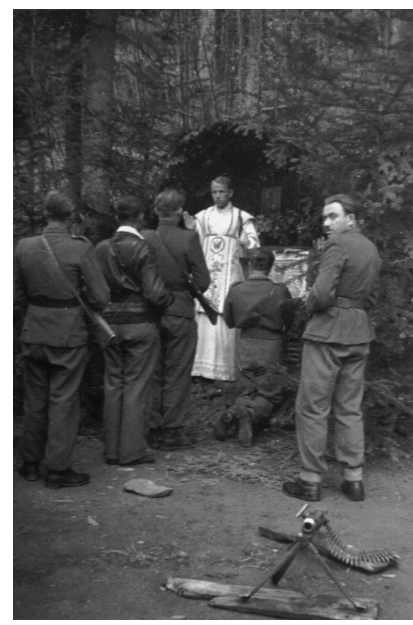

Il. 2. Władysław Gurgacz SJ odprawiający mszę św. dla żołnierzy Polskiej Podziemnej Armii Niepodległościowców na terenie Sądecczyzny.

Zbiory Archiwum PWM, Warszawa

Nieco mniej eksponowaną, choć równie ważną rolę odegrali liczni duszpasterze akademiccy działający w całej Polsce. Można choćby wspomnieć jezuitów duszpasterzy Katolickiego Uniwersytetu Lubelskiego Jana Pawła II (KUL), takich jak o. Jerzy Mirewicz ${ }^{14}$, o. Tomasz Rostworowski ${ }^{15}$ czy o. Hubert Czuma ${ }^{16}$.

do przyjaciót (wyboru listów dokonał i oprac. L. Grzebień, Kraków 1998); zob. Kozłowiecki Adam, w: EWJ, s. 315.

${ }^{14}$ Jerzy Mirewicz SJ (1909-1996), kaznodzieja, pisarz, redaktor. Podczas II wojny światowej był członkiem Związku Walki Zbrojnej i Armii Krajowej. W konspiracji działał głównie na Lubelszczyźnie. W latach 1945-1958 był duszpasterzem akademickim w Lublinie. Blisko współpracował z kard. Stefanem Wyszyńskim, na którego prośbę prowadził rekolekcje dla episkopatu Polski. Był członkiem organizacji oświatowych i literackich na emigracji (m.in. Polskiego Uniwersytetu na Obczyźnie) oraz kapelanem byłych żołnierzy AK; zob. Mirewicz Jerzy, w: EWJ, s. 427; K. Dorosz SJ, „,Wiek dwudziesty - nasz dom”. O twórczości Jerzego Mirewicza SJ, Torun 2011.

${ }^{15}$ Tomasz Rostworowski SJ (1904-1974), prefekt i nauczyciel muzyki jezuickiego Gimnazjum św. Kazimierza w Wilnie. Podczas II wojny światowej był kapelanem Komendy Głównej Armii Krajowej, angażował się w ratowanie Żydów. Pełnił posługę duszpasterza akademickiego w Łodzi (1945-1950) i w Lublinie (1957-1961). Był kierownikiem Sekcji Polskiej Radia Watykańskiego (1967-1974); zob. Rostworowski Tomasz, w: EWJ, s. 578-579; J.T. Granatowski, Niezwykty człowiek na trudne czasy. Życie i działalność o. Tomasza Rostworowskiego SJ, Warszawa 2011.

${ }^{16}$ Hubert Czuma SJ (1930-2019), w okresie 1961-1971 duszpasterz akademicki w Gdańsku i w Lublinie. Pod zarzutem przynależności do niepodległościowej organizacji „Ruch” został aresztowany w czerwcu 1970 r., zwolniony rok później z braku dowodów. Od 1979 r. był duszpasterzem młodzieży, kapelanem więziennym, duszpasterzem ludzi pracy oraz kapelanem NSZZ „Solidarność", z którą w latach 1980-1989 współpracował, a od 2003 r. był jej członkiem honorowym. 
Archiwum posiada w swoich zbiorach liczne zdjęcia ilustrujące działalność Duszpasterstwa Akademickiego KUL, a także fotografie z działalności zamkniętej już obecnie jezuickiej placówki przy ul. Królewskiej w Lublinie.

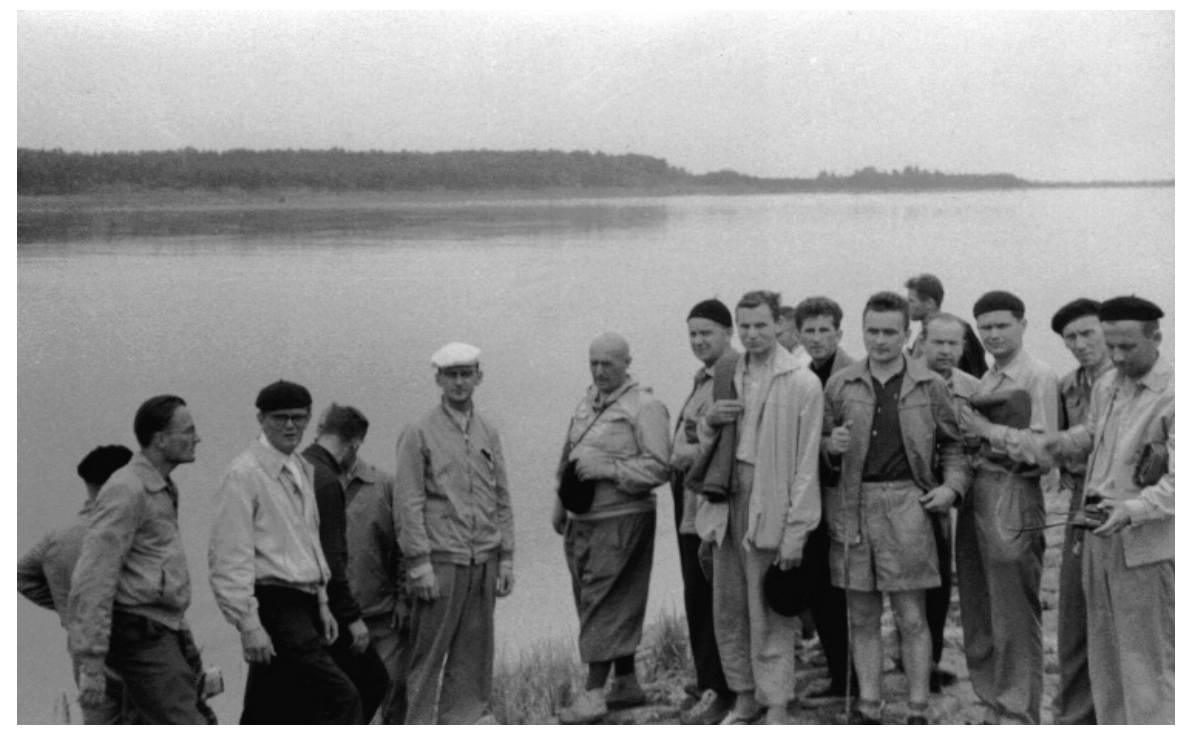

Il. 3. Tomasz Rostworowski SJ (w środku). Zbiory Archiwum PWM, Warszawa

Warto jeszcze dodać, że nie tylko historycy są zainteresowani zbiorami fotograficznymi Archiwum. Coraz częściej zdjęć jezuitów poszukują osoby spokrewnione z nimi, starające się odtworzyć dzieje swojej rodziny.

Zdjęcia członków Towarzystwa Jezusowego z oczywistych względów dominują liczebnie nad fotografiami osób nienależących do zakonu, wśród tych drugich nie brak jednak postaci ważnych dla historii Polski, zarówno duchownych, jak i świeckich.

W tej grupie wyróżnia się pokaźny zbiór zdjęć Jana Pawła II, m.in. z jego pielgrzymek do Polski, pochodzących z innych źródeł niż zdjęcia robione oficjalnie przez fotografów papieskich (takich jak np. Arturo Mari). Za przykład mogą posłużyć fotografie papieża z pielgrzymki do Polski w 1987 r., wykonane przez o. Floriana Pełkę, ówczesnego kierownika Sekcji Polskiej Radia Watykańskiego. Pozostawił on po sobie ok. 130 fotografii cy frowych, uwieczniających Jana Pawła II podczas spotkań oficjalnych (np. z gen. Wojciechem Jaruzelskim czy Lechem Wałęsą), ale także przy mniej formalnych okazjach, jak wyjazd na narty. Zdjęcia Ojca Świętego pozostawił nam również w formie cyfrowej o. Czesław Kozłowski.

Kolejny liczny zbiór fotografii dotyczy kard. Stefana Wyszyńskiego. Składają się na niego głównie zdjęcia wykonane przy okazjach różnych celebracji liturgicz-

W 2006 r. został odznaczony Krzyżem Komandorskim Orderu Odrodzenia Polski; zob. Czuma Hubert, w: EWJ, s. 114. Zob. także https://jezuici.pl/2019/09/zmarl-w-warszawie-o-hubert-czuma-sj/ (dostęp: 01.12.2021). 
nych, jak np. uroczystość koronacji obrazu Matki Bożej w Świętej Lipce 11 sierpnia 1968 r., oraz rozmaitych spotkań, oficjalnych i prywatnych.

Wśród zdjęć osób nienależących do zakonu znalazły się też pojedyncze fotografie przedstawiające ważne postaci Kościoła powszechnego. Za przykłady mogą służyć zdjęcia św. Matki Teresy z Kalkuty, wykonane 10 grudnia 1994 r. podczas jej wizyty w domu zgromadzenia sióstr Misjonarek Miłości przy ul. Grochowskiej w Warszawie, czy św. Urszuli Ledóchowskiej, założycielki Zgromadzenia Sióstr Urszulanek Serca Jezusa Konającego, a przy tym siostry W. Ledóchowskiego, generała Towarzystwa Jezusowego w latach 1915-1942. Archiwum posiada również pojedyncze, głównie portretowe, zdjęcia poprzedników Jana Pawła II na tronie Piotrowym - Jana Pawła I i Pawła VI.

Na wzmiankę zasługuje jeszcze jeden, niezwykle ciekawy zespół fotografii. Są to zdjęcia przedstawiające kapelanów Polskich Sił Zbrojnych na Zachodzie w czasie II wojny światowej. Zebrał je ks. Franciszek Mientki (1931-1982), kapłan Misjonarzy Ducha Świętego i kapelan Polskich Sił Zbrojnych na Zachodzie. Ostatecznie zbiór ten trafił do Archiwum PWM, choć dokładne okoliczności przekazania go nie są znane. Na otrzymany zbiór składają się zdjęcia portretowe, fotografie z ćwiczeń skakania ze spadochronem, a także zdjęcia okolicznościowe z parad i defilad wojskowych wojska szkockiego.

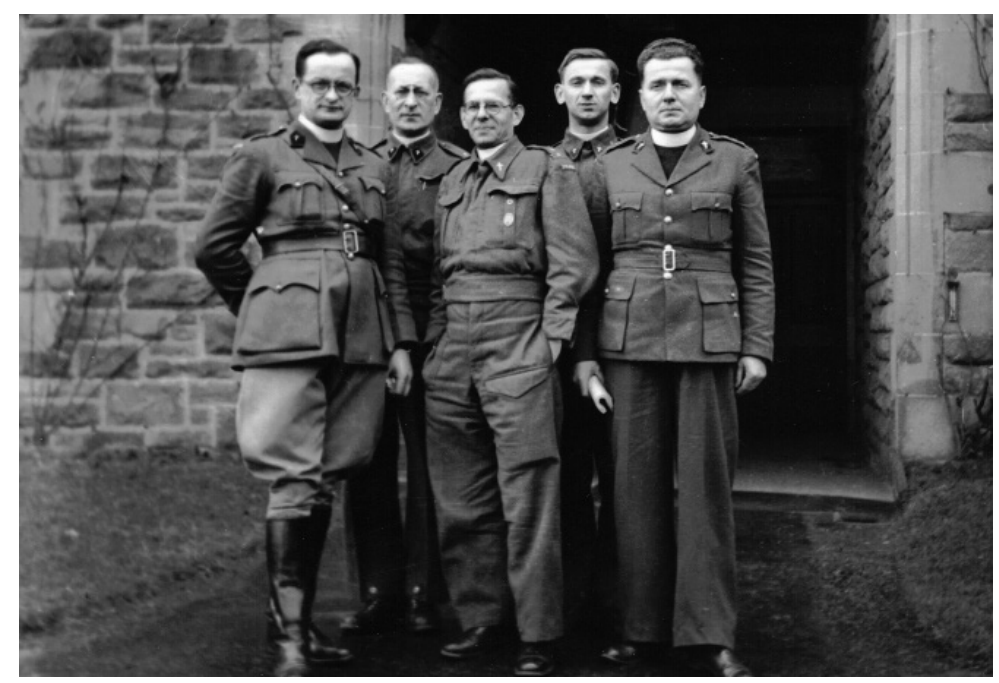

I1. 4. Kapelani Polskich Sił Zbrojnych na Zachodzie: ks. Franciszek Lorenc, ks. Konstanty Pogłódek, ks. Wacław Pyszkowski, o. Wiktor Hupa (Perth, 1941) Zbiory Archiwum PWM, Warszawa 


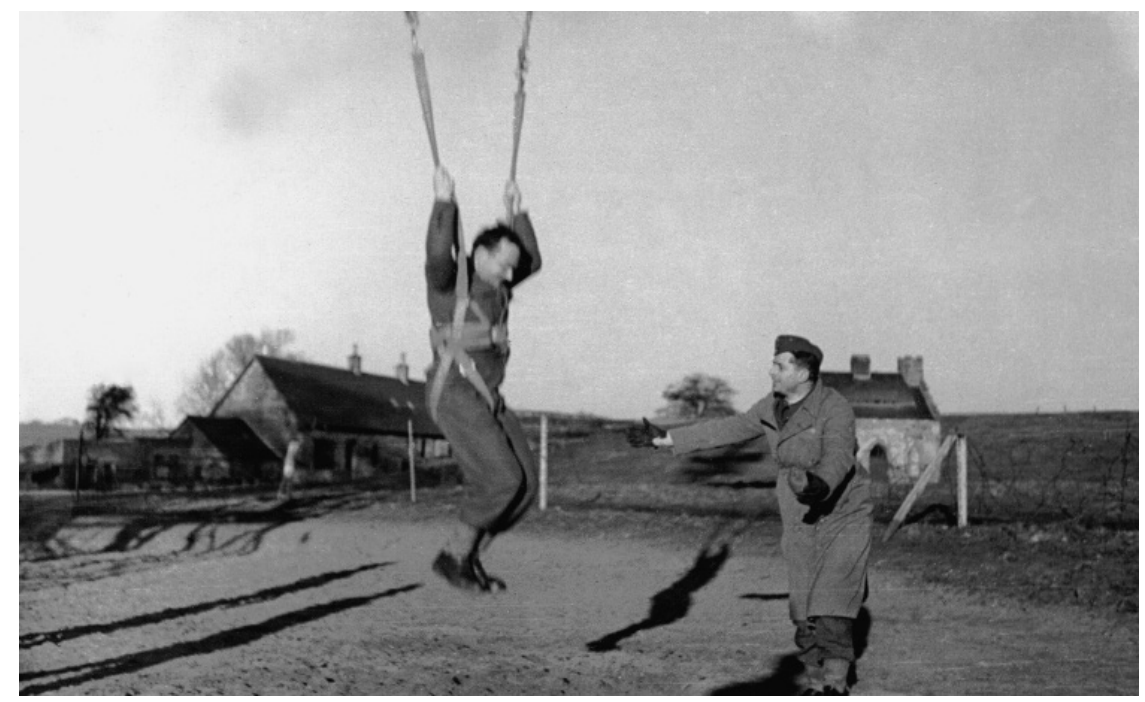

Il. 5. Skoki z wieży spadochronowej - ks. Franciszek Mientki, o. Hubert Misiuda (Largo, 1942). Zbiory Archiwum PWM, Warszawa.

W kategorii zdjęć osobowych dominują fotografie osób duchownych, można jednak wydzielić w niej mniejszy zbiór zdjęć osób świeckich. Czasem są to postaci znane, jak w przypadku fotografii Jerzego Hoppena, wieloletniego profesora sztuk plastycznych Uniwersytetu Mikołaja Kopernika w Toruniu i twórcy graficznej „Szkoły wileńskiej”, uchwyconego przy pracy nad freskami w Kościele Akademickim Ducha Świętego w Toruniu (1962). W zbiorach Archiwum znajdują się również dwie grafiki jego autorstwa z 1927 r., wykonane metodą akwaforty, przedstawiające Pałac Sapiehów na Antokolu oraz kościół św. Jana w Wilnie. Są to jednak pojedyncze przypadki, znacznie częściej jednak mamy do czynienia z fotografiami przedstawiającymi członków rodzin jezuitów oraz osób z nimi zaprzyjaźnionych. Za przykład mogą tu posłużyć zdjęcia z albumu rodzinnego o. H. Czumy. Jedno z nich to fotografia z chrztu (być może Huberta), przedstawiającą wielodzietną rodzinę Czumów przed wejściem do Kościoła Akademickiego KUL. Nie jest to przypadek - rodzina ta była związana z Lublinem i KUL w szczególności, jako że ojciec Huberta, Ignacy Czuma, był w latach 1926-1928 dziekanem Wydziału Prawa i Nauk Społeczno-Ekonomicznych KUL, a w latach 1938-1939 prorektorem uczelni. Na innym zdjęciu z tego samego albumu można znaleźć gen. Waleriana Czumę, dowódcę obrony Warszawy we wrześniu 1939 r. Niestety, tak dobrze opisane fotografie należą do rzadkości; przeważnie ustalenie tożsamości uchwyconych na nich osób nie jest możliwe.

Wśród zdjęć osób nienależących do zakonu można jeszcze wyróżnić zbiór fotografii członków prowadzonych przez jezuitów organizacji, ruchów i wspólnot działających w okresie między- i powojennym. Na uwagę zasługują zdjęcia 
dotyczące działalności Apostolstwa Modlitwy i Sodalicji Mariańskich ${ }^{17}$ oraz późniejszych Wspólnot Życia Chrześcijańskiego. Sodalicje Mariańskie były świeckimi stowarzyszeniami, powołanymi w celu łączenia życia chrześcijańskiego ze studiami i pracą. Przed wybuchem II wojny światowej działały w wielu ośrodkach na terenie całej Polski, skupiając głównie przedstawicieli inteligencji, nauczycieli szkolnych i akademickich oraz młodzieży. Po wojnie podjęto próbę ożywienia Sodalicji, zostało to jednak uniemożliwione przez dekret z 5 sierpnia 1949 r. o zmianie niektórych przepisów prawa o stowarzyszeniach. Po $1980 \mathrm{r}$. ruch ten zaczął się odradzać pod nową nazwą Wspólnot Życia Chrześcijańskiego. W zbiorach Archiwum znajduje się wiele zdjęć dokumentujących działalność tych stowarzyszeń. Za przykłady mogą posłużyć fotografie ze zjazdu Sodalicji Mariańskich, który odbył się w Lublinie 19-20 stycznia 1936 r., czy zjazdu sekcji sodalicyjnej Sierżantów Wojska Polskiego w Łodzi. Nota bene, do Sodalicji Mariańskiej w Łodzi w okresie międzywojennym przystąpił Jan Kozielewski, znany później jako Jan Karski ${ }^{18}$.

W zbiorach personalnych poszczególnych jezuitów znajdują się również fotografie przedstawiające inne ruchy i wspólnoty religijne, jak Ruch Światło-Życie, Odnowa w Duchu Świętym czy Droga Neokatechumenalna.

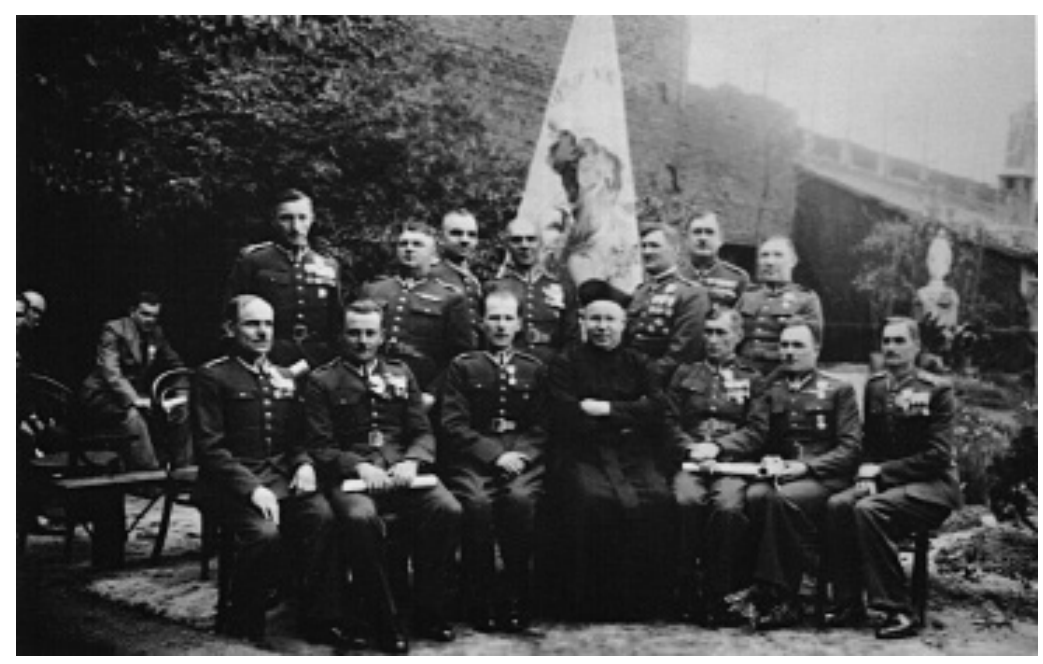

Il. 6. Sekcja sodalicyjna Sierżantów Wojska Polskiego przy kościele oo. Jezuitów w Łodzi przed 1939 r. Zbiory Archiwum PWM, Warszawa

${ }^{17}$ Zob. Sodalicja Mariańska, w: EWJ, s. 629-630.

${ }^{18}$ Zob. K. Dorosz SJ, Temat Holokaustu na łamach emigracyjnego „Przegladu Powszechnego", w: Jan Karski. Świadek, emisariusz, człowiek, red. A. Kasperek, A. Żmuda, S.J. Żurek, Lublin 2015, s. 203-204. 


\section{Zdjęcia obiektów}

Drugi, niezwykle ważny zespół zdjęć w posiadaniu Archiwum PWM stanowią fotografie przedstawiające obiekty jezuickie: kościoły, domy i dzieła. Można tu wyodrębnić zbiory zdjęć placówek, które wciąż istnieją i działają, oraz tych, które z różnych powodów zostały już zamknięte. $Z$ archiwalnego i historycznego punktu widzenia najważniejszą rolę odgrywa dokumentacja obiektów już nieistniejących, zarówno znajdujących się na terenach II Rzeczpospolitej nienależących dziś do Polski (jak np. Wilno, Lwów, Chyrów, Albertyn, Pińsk), jak i tych, które były położone $\mathrm{w}$ obecnych granicach kraju (Bobolanum i placówka przy ul. Królewskiej w Lublinie, kościoły i domy w Gdańsku, Łęczycy, Grudziądzu, Łodzi).

Jednym z większych i ciekawszych zbiorów fotografii z tej kategorii jest ten dotyczący budynku dawnego lubelskiego Kolegium Bobolanum ${ }^{19}$. Był to Wydział Teologiczny Towarzystwa Jezusowego kształcący kleryków jezuickich i diecezjalnych, współpracujący z Katolickim Uniwersytetem Lubelskim. W 1923 r., według projektu architekta Ignacego Kędzierskiego, rozpoczęła się budowa budynku Bobolanum. Jezuicki Wydział Teologiczny został przeniesiony w $1926 \mathrm{r}$. z Krakowa do nowej siedziby mieszczącej się przy Alejach Racławickich. Biblioteka Wydziału dotarła tam kilka lat później, w 1933 r. Posiadała ok. 70 tys. tomów, duży zbiór starodruków (ok. 10 tys. tomów) i była stale uzupełniania. Po wybuchu II wojny światowej księgozbiór przeniesiono do Biblioteki im. H. Łopacińskiego, a następnie zdeponowano w Bibliotece Uniwersyteckiej KUL. W połowie lat 60. XX wieku zbiory biblioteczne zostały przewiezione do Kolegium Jezuitów w Warszawie.

Dnia 1 września 1939 r. budynek Kolegium Bobolanum w Lublinie został przekształcony na polski szpital wojskowy, zaś niedługo później przejęty przez okupanta niemieckiego. Mimo to w październiku tego samego roku zajęcia studiów teologicznych rozpoczęły się w wynajętych pomieszczeniach. Na przełomie lat 1939 i 1940 duża część wspólnoty Bobolanum została aresztowana i osadzona na Zamku w Lublinie, a następnie przewieziona do obozów koncentracyjnych w Sachsenhausen i w Dachau. Po II wojnie światowej w gmachu mieszkało jeszcze kilku jezuitów, ale ostatecznie usunięto ich w $1951 \mathrm{r}$. Budynek pozostał szpitalem wojskowym - obecnie mieści się tam Wojskowy Szpital Kliniczny.

Bobolanum posiadało majątek ziemski w Dąbrowicy ${ }^{20}-45$ ha ziemi rolnej, lasów i stawów. Częściowo zaspokajał on zapotrzebowanie na żywność, znajdowała się tu też willa służąca za miejsce wypoczynku dla profesorów i kleryków.

Archiwum PWM posiada dokumentację fotograficzną z budowy Kolegium, życia wspólnoty jezuitów tam przebywających (jak portrety członków uczelnianej orkiestry i teatru), a także zdjęcia pomieszczeń i wyposażenia budynku. Zdjęcia te pozwalają na historyczną rekonstrukcję rozkładu i wyglądu pomieszczeń oraz ich wyposażenia.

\footnotetext{
${ }^{19}$ Zob. Wydział Teologiczny ,Bobolanum”, w: EWJ, s. 770-772.

${ }^{20}$ Tamże, s. 120.
} 


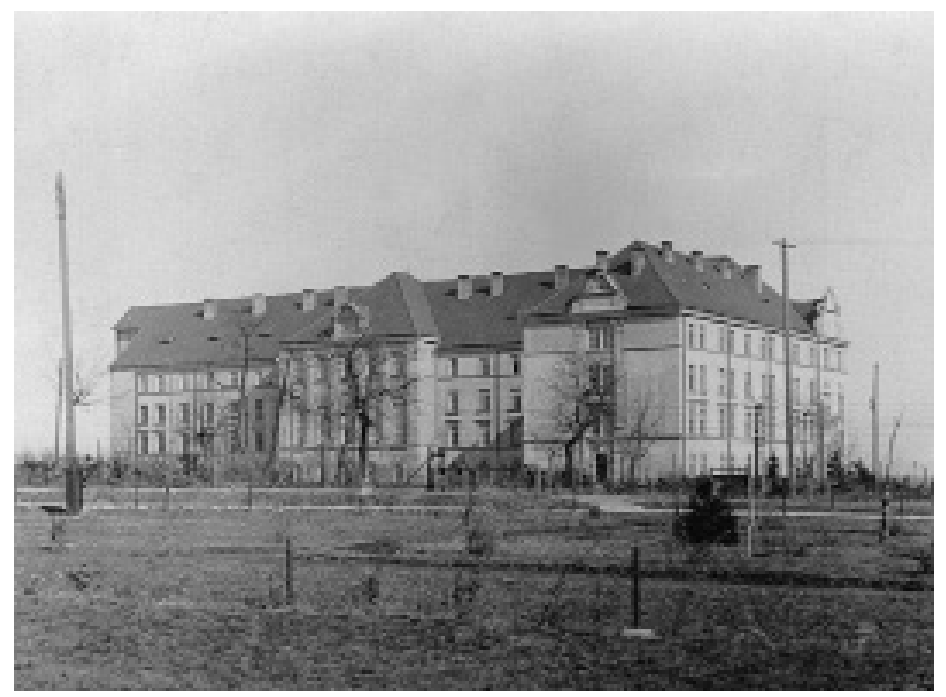

Il. 7. Budynek Kolegium Bobolanum przy Alejach Racławickich w Lublinie. Zbiory Archiwum PWM, Warszawa

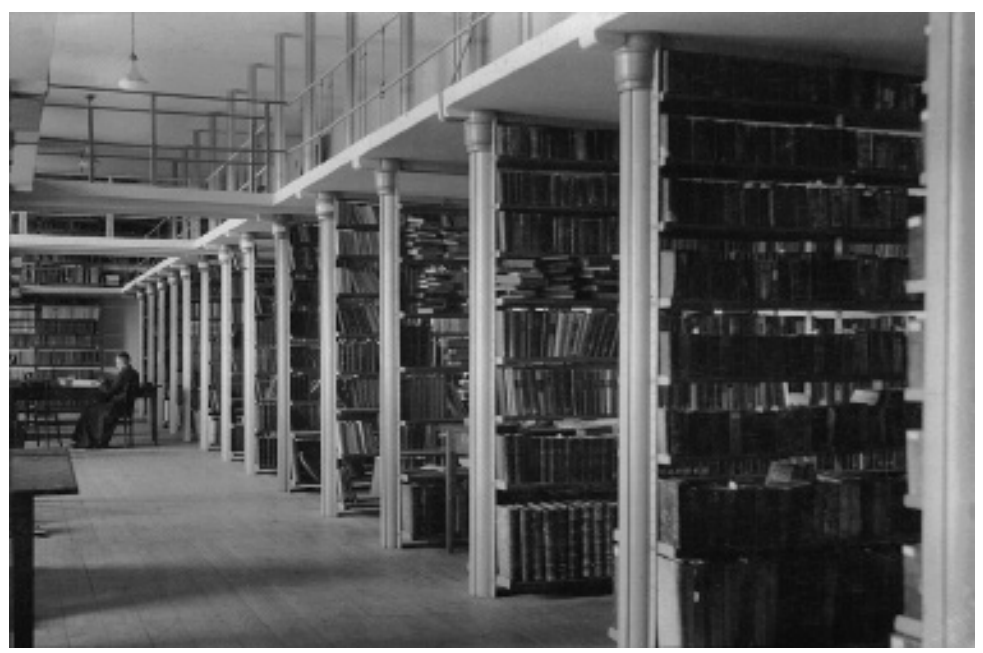

Il. 8. Biblioteka Kolegium Bobolanum przy Alejach Racławickich w Lublinie. Zbiory Archiwum PWM, Warszawa

Drugą ważną, a nieistniejącą już instytucją jezuicką, której bogata dokumentacja znajduje się w Archiwum PWM, jest Kolegium i Gimnazjum św. Kazimierza w Wilnie ${ }^{21}$, działające w latach 1918-1940.

Pierwsze lata funkcjonowania Gimnazjum były trudne, a jego istnienie zagrożone z powodu naprzemiennego przejmowania kontroli nad Wilnem przez wojska

${ }^{21}$ Tamże, s. 746. 
polskie i bolszewickie. Szkoła jako gimnazjum rozpoczęła działalność w 1922 r., ale pełne prawa gimnazjum państwowego otrzymała dopiero w 1925 r. Placówka rozwijała się jednak szybko i w 1926 r. liczyła już ponad 400 uczniów. Urządzono tu gabinety naukowe, biblioteki i muzea. Szkoła miała własną orkiestrę i teatr. Wielu wychowanków Gimnazjum odegrało ważną rolę w historii Polski, jak np. pisarz emigracyjny Aleksander Blum, aktor Zygmunt Kęstowicz, historyk i działacz emigracyjny Zbigniew Siemaszko czy oficer Armii Krajowej Roman Korab-Żebryk. W okresie powojennym część z nich zawiązała Koło Byłych Wychowanków Gimnazjum O.O. Jezuitów w Wilnie, które przygotowało i wydało cenną monografię szkoły ${ }^{22}$. Niemal całość materiałów zebrana na okoliczność tego opracowania trafiła ostatecznie do Archiwum. W naszych zbiorach znajduje się pokaźny zespół dokumentów i zdjęć dotyczący działalności tej placówki w okresie międzywojennym. Materiał fotograficzny obejmuje różne przejawy życia szkolnego - od zdjęć kadry profesorskiej i uczniów (zarówno oficjalnych, jak i mniej formalnych), po wydarzenia z życia szkoły (defilady, biegi narciarskie, ćwiczenia hufca konnego). Zachowały się też fotografie zabudowań szkolnych. Obecnie w budynkach dawnego Gimnazjum św. Kazimierza w Wilnie znajduje się Wileńskie Gimnazjum Jezuitów ${ }^{23}$.

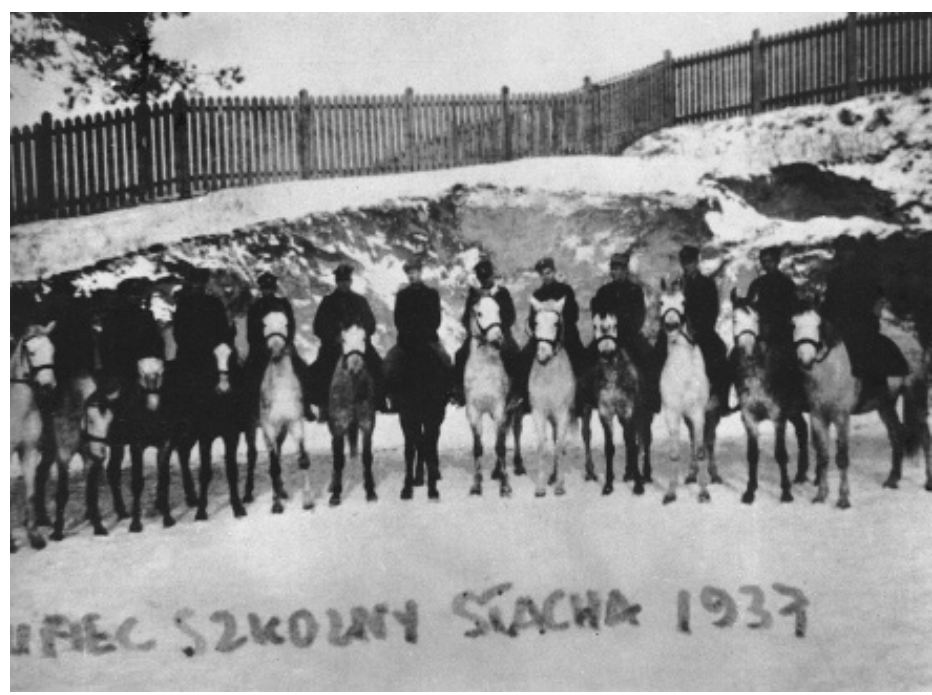

Il. 9. Ćwiczenia hufca konnego Gimnazjum Ojców Jezuitów w Wilnie (1937) Zbiory Archiwum PWM, Warszawa

${ }^{22}$ Zob. Gimnazjum Ojców Jezuitów w Wilnie w latach 1922-1940 (monografia), red. R. Cybulski i in., Bydgoszcz [1997].

${ }^{23} \mathrm{~W}$ czasach sowieckich działała tam szkoła państwowa, a pod koniec epoki ZSRR kompletnie zdewastowany budynek zaczęto remontować, co jednak szło nieudolnie. W połowie lat 90 . ubiegłego stulecia obiekt zwrócono jezuitom prowincji litewskiej, którzy z pomocą państwa dokończyli remont i założyli tam gimnazjum, a ostatnio całość rozbudowali o bibliotekę; zob. Vilniaus jèzuitu gimnazija (vjg.lt) (dostęp: 02.12.2021). 
Mniej liczny zbiór, niż ten dokumentujący placówkę w Wilnie, stanowi zespół zdjęć dotyczących działalności Zakładu Naukowo-Wychowawczego Ojców Jezuitów pod wezwaniem św. Józefa w Bąkowicach pod Chyrowem ${ }^{24}$, działającego w latach 1886-1939. Zakład składał się z siedmioklasowej szkoły podstawowej, szkoły średniej oraz konwiktu. Była to doskonale wyposażona placówka edukacyjna, posiadająca m.in. pokaźną bibliotekę (30 tys. tomów), pracownie do prac rękodzielniczych (w drewnie, metalu i szkle), pracownię biologiczną ze szkolnym ogrodem botanicznym, muzeum przyrodnicze czy obserwatorium astronomiczne. Działały tu teatr i orkiestra, funkcjonowała też Sodalicja Mariańska uczniów.

Chyrowski zakład wykształcił i wychował ok. 7 tys. uczniów, w tym wiele ważnych postaci życia publicznego końca XIX i XX wieku. Absolwentami byli m.in. malarz Adam Styka, historyk nauk ścisłych i filozofii Aleksander Birkenmajer, minister II Rzeczypospolitej Eugeniusz Kwiatkowski, poeta Kazimierz Wierzyński czy kard. A. Kozłowiecki. W zbiorach Archiwum znajdują się zdjęcia przedstawiające szkolne zabudowania, niektóre pracownie, grono pedagogiczne i uczniów oraz ilustracje aktywności pozalekcyjnych. Część fotografii tej placówki pochodzi z folderu reklamowego, wydanego przez samą szkołę.

Kolejną ważną jezuicką placówką edukacyjną było kolegium i kościół w Piń$\mathrm{sku}^{25}$. Obiekty te należały do zakonu przed kasatą, wznowiły działalność w $1919 \mathrm{r}$. jako gimnazjum dla kleryków jezuickich przygotowujących się do matury. Grono profesorskie stanowili głównie jezuici. W 1937 r. przeniesiono tu nowicjat Prowincji Wielkopolsko-Mazowieckiej Towarzystwa Jezusowego. Kolegium przestało istnieć we wrześniu 1939 r., po wkroczeniu do Pińska wojsk sowieckich.

\section{Zdjęcia wydarzeń}

Kolejną dużą i ważną grupę zdjęć w posiadaniu Archiwum PWM stanowią fotografie ilustrujące wydarzenia historyczne, ważne nie tylko dla zakonu, ale także dla kraju i społeczeństwa. Zbiór ten zawiera dokumentację wydarzeń z okresu międzywojennego, czasów II wojny światowej oraz lat powojennych.

Przykładem ujęcia zdarzenia ważnego dla całego kraju jest zdjęcie z pogrzebu marszałka Józefa Piłsudskiego, który odbył się w Krakowie 18 maja 1935 r., kończąc uroczystości żałobne trwające od 13 maja. Z kolei dla Kościoła katolickiego w II Rzeczypospolitej ważnym wydarzeniem było sprowadzenie do Polski relikwii św. Andrzeja Boboli ${ }^{26}$, po jego kanonizacji w Rzymie 17 kwietnia 1938 r. Relikwie przywieziono do kraju pociągiem, witano je w różnych miastach podczas specjalnie zorganizowanych wielkich uroczystości. Na zdjęciach ze zbiorów Archiwum uwieczniono różne momenty tej peregrynacji, m.in. powitanie relikwii w Poznaniu.

\footnotetext{
${ }^{24}$ Zob. Chyrów, w: EWJ, s. 96-98.

${ }^{25}$ Zob. Pińsk, w: EWJ, s. 510.

${ }^{26}$ Zob. Andrzej Bobola, w: EWJ, s. 10.
} 


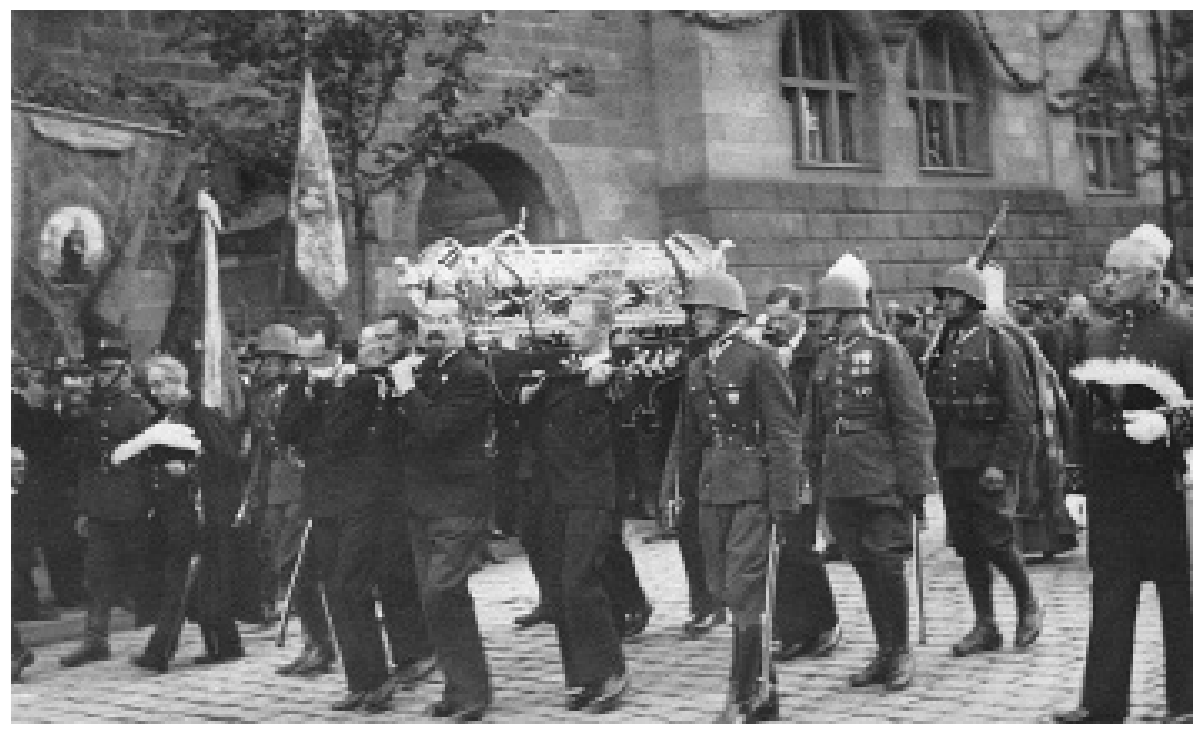

Il. 10. Sprowadzenie relikwii św. Andrzeja Boboli do Polski - uroczystości w Poznaniu.

Fot. Foto-Express, Majewski. Zbiory Archiwum PWM, Warszawa

Niektóre wydarzenia historyczne trudno uchwycić bezpośrednio, zamiast tego uwieczniane są ich skutki. Tak jest w przypadku zdjęć obrazujących zniszczenia wojenne, głównie Warszawy i jej odbudowę. Archiwum posiada dokumentację dotyczącą losów kościoła Najświętszej Marii Panny Łaskawej przy ul. Świętojańskiej ${ }^{27}$. Przed II wojną światową w kamienicy obok kościoła mieściła się siedziba Kurii Prowincji i rezydencja zakonna. Czynna pozostała do powstania warszawskiego. W stolicy jezuici współpracowali z Armią Krajową, urządzając dni skupienia i rekolekcje dla żołnierzy. Przechowywali też archiwum bazy „Wachlarz” i przez jakiś czas radiostację ${ }^{28}$. Zarówno kościół, jak i rezydencja, wraz ze znajdującym się w niej archiwum, zostały w czasie walk powstańczych całkowicie zniszczone. Zdjęcia w posiadaniu Archiwum dokumentują historię kościoła. W pierwszej kolejności są to fotografie fasady i wnętrza przed $1939 \mathrm{r}$. Następnie gruzy kościoła, w tym niezwykłe zdjęcie przedstawiające kondukt pogrzebowy z trumną prymasa Augusta Hlonda, zmierzający do pobliskiej katedry św. Jana Chrzciciela w Warszawie (wciąż odbudowywanej), mający w tle ruiny jezuickiego sanktuarium. Po tym wreszcie następuje bogata dokumentacja fotograficzna trwającego w latach 1950-1952 procesu odbudowy kościoła Najświętszej Marii Panny Łaskawej i domu zakonnego, począwszy od zbiórki ofiar na ten cel, po rekonstrukcję dachu.

\footnotetext{
${ }^{27}$ Zob. Warszawa-Rezydencja NMP Laskawej, w: EWJ, s. 722.

${ }^{28}$ Tamże.
} 


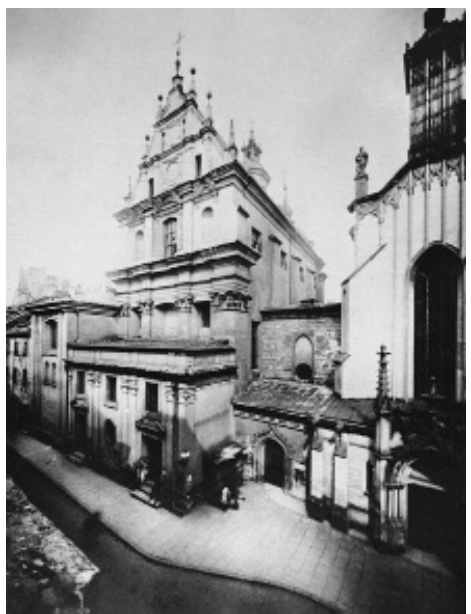

Il. 11. Sanktuarium Najświętszej Marii

Panny Łaskawej przy ul. Świętojańskiej w Warszawie przed zniszczeniem podczas powstania warszawskiego.

Zbiory Archiwum PWM, Warszawa

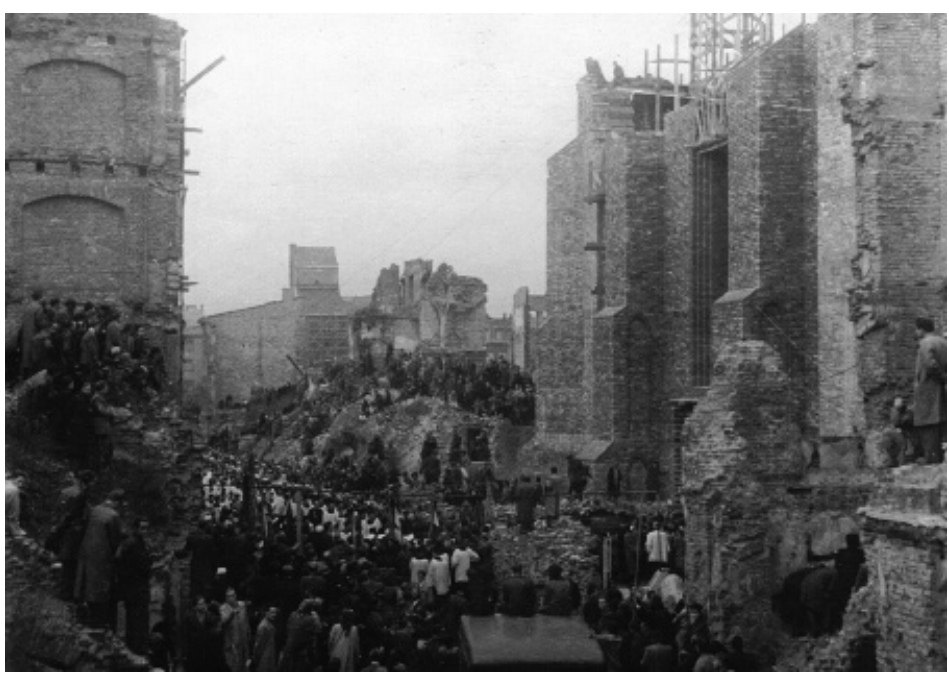

Il. 12. Kondukt z trumną prymasa Augusta Hlonda zmierzający do katedry św. Jana Chrzciciela w Warszawie (1948). W tle ruiny kościoła Najświętszej Marii Panny Łaskawej. Zbiory Archiwum PWM, Warszawa 


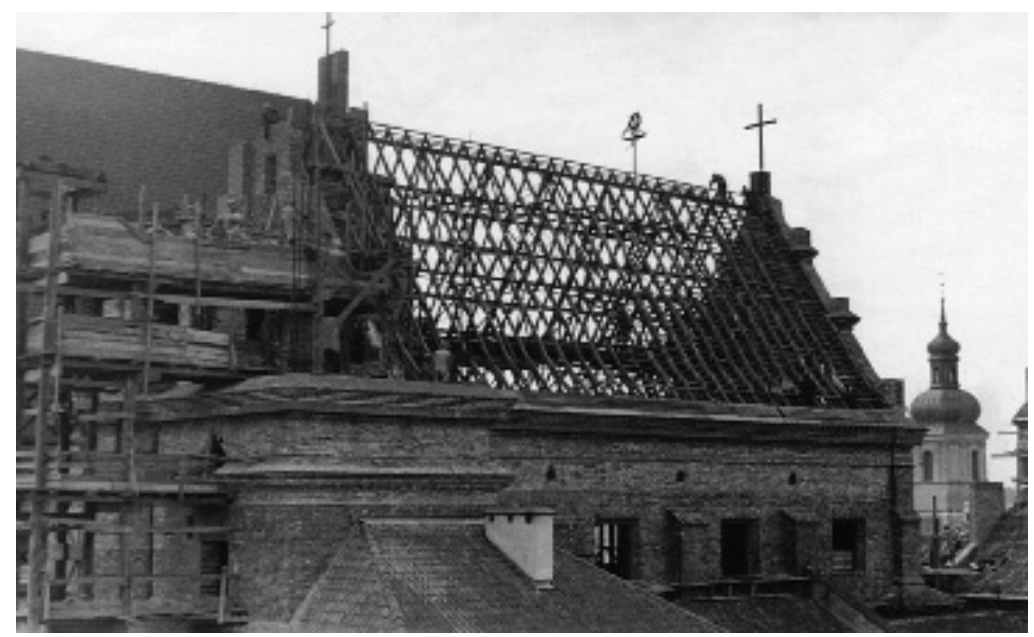

Il. 13. Odbudowa kościoła Najświętszej Marii Panny Łaskawej (1950-1952) Zbiory Archiwum PWM, Warszawa

Tragicznym wydarzeniem dotyczącym Towarzystwa Jezusowego, a jednocześnie wiążącym się ściśle z losami powstania warszawskiego, była masakra w dawnym Domu Pisarzy przy ul. Rakowieckiej. Doszło do niej drugiego dnia walk powstańczych. Z rąk oddziału SS zginęły 44 osoby - 16 jezuitów oraz osoby świeckie, które schroniły się w ich domu ${ }^{29}$. Po masakrze pomieszczenia na parterze zostały podpalone, spłonęła także część księgozbioru. Na zbiór zdjęć dokumentujących tę tragedię składają się fotografie domu (z widocznymi na fasadzie śladami kul), wypalone wnętrza, zdjęcia zrobione podczas późniejszej ekshumacji ofiar oraz fotografie kaplicy utworzonej w miejscu kaźni. Część z tych fotografii została zebrana i opisana przez o. Karola Sawickiego, jednego z kilku jezuitów, którym udało się przeżyć masakrę. Spisane przez niego świadectwo Stos ofiarny zostało wydane w niewielkim nakładzie w Rzymie ${ }^{30}$.

Kolejnym obiektem związanym z jezuitami, którego wojenne losy zostały uchwycone na zdjęciach ze zbiorów Archiwum, jest dawny kościół jezuicki pw. św. Ignacego Loyoli w Bydgoszczy ${ }^{31}$. Choć obiekt ten przestał należeć do Towarzystwa Jezusowego po kasacie zakonu w 1773 r., zakon nie przestał interesować się jego losami. Kolegium i kościół zbudowane zostały w XVII wieku. Podczas okupacji w 1940 r. dawny kościół jezuicki na Rynku Głównym został rozebrany decyzją władz niemieckich. W Archiwum zachowały się unikatowe zdjęcia dokumentujące proces tej rozbiórki, która miała miejsce w okresie styczeń-sierpień $1940 \mathrm{r}^{32}$ Cennym uzupełnieniem tego zbioru jest pocztówka z 1912 r., na której uwieczniono kościół i Stary Rynek w Bydgoszczy w pełnej krasie.

${ }^{29}$ Zob. Warszawa, ul Rakowiecka 61, w: EWJ, s. 723; Masakra w klasztorze, oprac. F. Paluszkiewicz, Warszawa 2003.

${ }^{30}$ K. Sawicki, Stos ofiarny, Rzym 1976.

${ }^{31}$ Zob. Bydgoszcz, w: EWJ, s. 80-81.

${ }^{32}$ A. Siwiak, W. Siwiak, Zabudowania jezuickie w najnowszych badaniach archeologicznych, w: Jezuici w Bydgoszczy i okolicy, red. M. Puziak, Bydgoszcz 2018, s. 187-217. 
Nie tylko tragiczne wydarzenia doczekały się dokumentacji fotograficznej. Archiwum posiada dość liczny zbiór zdjęć z rozmaitych uroczystości kościelnych, tak zewnętrznych, jak i wewnątrzzakonnych. Do pierwszej grupy można zaliczyć relację zdjęciową z koronacji obrazów Matki Bożej w Świętej Lipce (1968) i w Sanktuarium Matki Bożej Łaskawej w Warszawie (1973). Uroczystej koronacji koroną papieską dokonał w bazylice archikatedralnej św. Jana Chrzciciela w Warszawie kard. S. Wyszyński. Na odwrocie korony znalazł się napis: „Łaskawej Patronce Stolicy w kościele XX. Jezuitów, z wdzięcznością za łaski i prośbą o Matczyną Opiekę nad Miastem Nieujarzmionym - Stefan Kardynał Wyszyński”. Uroczystości, przy licznym udziale wiernych, a także delegacji zagranicznych, odbywały się w dniach 6-7 października 1973 r. Do tej kategorii zaliczyć można też zdjęcia z uroczystości milenijnych w 1966 r., z pielgrzymek Jana Pawła II do Polski, a także dokumentację lokalnych uroczystości w różnych kościołach jezuickich w kraju.

Archiwum, rzecz jasna, posiada również bogaty zbiór zdjęć ważnych wydarzeń jezuickich. Należy do nich wizyta generała zakonu, dziś kandydata na ołtarze, o. Pedro Arrupe w maju 1969 r., a także wizyty kolejnych generałów: P.H. Kolvenbacha, Adolfo Nicolasa i Arturo Sosy ${ }^{33}$. Oprócz tego udokumentowane zostały Kongregacje Prowincji i szereg różnych uroczystości wewnątrzzakonnych, takich jak śluby zakonne, święcenia kapłańskie, jubileusze kapłaństwa czy uroczystości ku czci świętych jezuickich (Ignacego Loyoli, Andrzeja Boboli, Stanisława Kostki, Jana Beyzyma).

\section{Zdjęcia artystyczne}

Ostatnią, ważną kategorię w zbiorach Archiwum PWM stanowią zdjęcia wykonane przez jezuitów - pasjonatów fotografii. Można tu wymienić nieżyjących już oo. Cz. Kozłowskiego ${ }^{34}$, Jacka Pleskaczyńskiego ${ }^{35}$, F. Pełkę ${ }^{36}$, Stanisława

${ }^{33}$ Przełożeni generalni Towarzystwa Jezusowego w latach 1965-1983, 1983-2008, 2008-2016 i od 2016 r. do dziś.

${ }^{34}$ Czesław Kozłowski SJ (1944-2013), wykładowca teologii duchowości na Wydziale Teologicznym Bobolanum w Warszawie, psycholog, mistrz nowicjatu i instruktor tzw. trzeciej probacji, przełożony w Gdyni i Jastrzębiej Górze; członek Związku Polskich Fotografów Przyrody, pasjonat fotografii; zob. Kozłowski Czesław, w: EWJ, s. 315-316. Zob. także https://jezuici.pl/2012/09/zmarl -o-czeslaw-kozlowski-sj/ (dostęp: 01.12.2021).

${ }^{35}$ Jacek Pleskaczyński SJ (1948-2019), duszpasterz akademicki w Toruniu i w Łodzi, zaangażowany w animowanie życia duchowego harcerzy, licealistów i kombatantów oraz środowisk opozycyjnych; współprowadził Duszpasterstwo Środowisk Twórczych. Pracował jako kapelan szpitala MSWiA w Warszawie, misjonarz ludowy w Poznaniu oraz duszpasterz akademicki i rekolekcjonista w Szczecinie. Krótko przed śmiercią został odznaczony Krzyżem Oficerskim Orderu Odrodzenia Polski oraz Krzyżem Wolności i Solidarności; zob. Pleskaczyński Jacek, w: EWJ, s. 516. Zob. także https://jezuici.pl/2019/08/zmarl-o-jacek-pleskaczynski-sj/; https://ipn.gov.pl/pl/ aktualnosci/75628,Pozegnalismy-o-Jacka-Pleskaczynskiego.html (dostęp: 01.12.2021).

${ }^{36}$ Florian Pełka SJ (1937-2019), teolog, wykładowca KUL. W latach 70. XX wieku pełnił funkcję superiora rezydencji w Lublinie. W okresie 1972-1976 pracował na KUL jako asystent w Katedrze Socjologii Religii w Instytucie Teologii Pastoralnej. Od 1976 r. przebywał w Rzymie, gdzie związany był z Sekcją Polską Radia Watykańskiego (od 1980 r. na stanowisku kierownika). Był uczestnikiem i korespondentem pielgrzymek Jana Pawła II. W latach 1991-1997 sprawował urząd 
Pacholika ${ }^{37}$. Prace oo. Cz. Kozłowskiego i J. Pleskaczyńskiego były wysoko cenione przez znawców fotografii.

Ojciec Cz. Kozłowski był bardzo wszechstronnym fotografem. Dużo podróżował po całym kraju i po świecie. W jego zbiorach znajdują się zdjęcia z wyprawy do miejsc związanych ze świętymi jezuitami: Ignacym Loyolą, Franciszkiem Ksawerym, Piotrem Faberem, Andrzejem Bobolą. Odwiedził m.in. Skandynawię, Czechy, Słowację, Białoruś, Turcję, Egipt, Chiny i kraje Ameryki Łacińskiej. Gdziekolwiek dotarł, fotografował zabytki (np. ruiny starożytnego Efezu czy Wielki Mur Chiński) i ludzi, z którymi się spotykał, najchętniej jednak uwieczniał piękno przyrody. Pozostawił po sobie wiele zapierających dech w piersiach zdjęć krajobrazów, egzotycznych roślin i zwierząt. Na bazie zrobionych przez siebie zdjęć opublikował wiele albumów, m.in. o pielgrzymkach Jana Pawła II, o Jastrzębiej Górze, o morzu i pięknie przyrody. Wydał również książkę Glosy natury. Refleksje religijne fotografa natury ${ }^{38}$. Jego zdjęcia były eksponowane na wielu wystawach fotograficznych.

Ojciec Jacek Pleskaczyński pozostawił po sobie zdjęcia zarówno w formie cyfrowej, jak i wywołanych pozytywów. Sporo podróżował, m.in. do Bułgarii, Kanady i Meksyku. Wśród fotografii z tych podróży znaleźć można zdjęcia etnograficzne, pokazujące miasteczka, rękodzieło i codzienne życie mieszkańców, a także zdjęcia starożytnych ruin oraz lokalnej fauny i flory. Był pasjonatem przyrody, jego ulubiony temat fotografii stanowiły ptaki. Udało mu się uchwycić te często spotykane, jak sikorki, kosy i wróble, ale także ptaki drapieżne (m.in. jastrzębie), a nawet objęte na terenie Polski ochroną (np. głuszce). Jego ulubionym i często fotografowanym regionem było Roztocze.

\section{Podsumowanie}

Zdjęcia ze zbiorów Archiwum Prowincji Wielkopolsko-Mazowieckiej Towarzystwa Jezusowego zachowały dla współczesności wiele informacji o wydarzeniach niespokojnego XX wieku. Opowiadają historie ludzi, którzy już odeszli, oraz miejsc, które dziś nie istnieją. Czasem są jedynymi świadectwami przeszłości. Pozostają cennym materiałem źródłowym i w ostatnim czasie daje się zauważyć wyraźny wzrost zainteresowania nimi, nie tylko ze strony „zawodowych” historyków, ale też pasjonatów historii, a nawet osób niezajmujących się przeszłością Polski, ale poszukujących własnych korzeni rodzinnych. Stąd tak ważną kwestią jest dbałość o odpowiednie przechowywanie zbiorów fotograficznych. Należy mieć nadzieję, że wraz z towarzyszącymi im źródłami pisanymi fotografie

prowincjała Prowincji Wielkopolsko-Mazowieckiej Towarzystwa Jezusowego; zob. Pełka Florian, w: EWJ, s. 498. Zob. także M. Fijołek, Pełka Florian SJ, w: Encyklopedia 100-lecia KUL, t. 2, red. E. Gigilewicz, Lublin 2018, s. 175; https://jezuici.pl/2019/10/zmarl-o-florian-pelka-sj/ (dostęp: 01.12.2021).

${ }^{37}$ Stanisław Pacholik SJ (1961-2018), katecheta oraz duszpasterz dzieci i młodzieży w Warszawie, Szczecinie i w Piotrkowie Trybunalskim; zob. Pacholik Stanisław, w: EWJ, s. 487. Zob. także https://jezuici.pl/2018/09/zmarl-o-stanislaw-pacholik-sj/ (dostęp: 01.12.2021).

${ }^{38} \mathrm{Cz}$. Kozłowski SJ, Glosy natury. Refleksje religijne fotografa przyrody, Warszawa 2010. 
archiwalne ze zbiorów Archiwum przyczynią się w przyszłości do powstania wielu interesujących prac historycznych.

\section{REFERENCES / BIBLIOGRAFIA}

\section{Źródla}

Catalogus Provinciae Poloniae Maioris et Mazoviae Societatis Iesu 1939-1945: Odpowiedzi na kwestionariusz do dzieła „,Kościół katolicki a okupacja niemiecka 1939-1945”, Archiwum Prowincji Wielkopolsko-Mazowieckiej Towarzystwa Jezusowego, Warszawa 1948, [mps].

\section{Opracowania}

50 lat Prowincji Wielkopolsko-Mazowieckiej Towarzystwa Jezusowego (1926-1976). Sylwetki i wspomnienia, Rzym 1976.

Dorosz Krzysztof SJ, Temat Holokaustu na łamach emigracyjnego „Przegladu Powszechnego”, w: Jan Karski. Świadek, emisariusz, człowiek, red. A. Kasperek, A. Żmuda, S.J. Żurek, Lublin 2015, s. 203-212.

Dorosz Krzysztof SJ, ,, Wiek dwudziesty-nasz dom”. O twórczości Jerzego Mirewicza SJ, Toruń 2011.

Encyklopedia wiedzy o jezuitach na ziemiach Polski i Litwy 1564-1995, red. L. Grzebień, Kraków 2004.

Fijołek Mirosław, Pełka Florian SJ, w: Encyklopedia 100-lecia KUL, t. 2, red. E. Gigilewicz, Lublin 2018, s. 175.

Gimnazjum Ojców Jezuitów w Wilnie w latach 1922-1940 (monografia), red. R. Cybulski $\mathrm{i}$ in., Bydgoszcz [1997].

Golik Dawid, Musiał Filip, Władysław Gurgacz. Jezuita wyklęty, Kraków 2014.

Granatowski Jacek T., Niezwykly człowiek na trudne czasy. Życie i działalność o. Tomasza Rostworowskiego SJ, Warszawa 2011.

Gurgacz Władysław SJ, Refleksje, oprac. M. Chodyko przy współpracy K. Dorosza SJ, Warszawa 2020.

Historia domów Prowincji Wielkopolsko-Mazowieckiej Towarzystwa Jezusowego, cz. 2: (1939-1945), oprac. T. Pronobis, Archiwum PWM, Warszawa 2002, [kmps].

Kołacz Jakub, Stownik języka i kultury jezuitów polskich, Kraków 2006.

Kozłowski Czesław SJ, Głosy natury. Refleksje religijne fotografa przyrody, Warszawa 2010.

Masakra w klasztorze, oprac. F. Paluszkiewicz, Warszawa 2003.

Musiał Filip, Ks. Władysław Gurgacz „,Sem”, Kraków 2020.

Noszczak Bartłomiej, Za klasztorna furta. Migawki z życia $i$ działalności jezuitów w Warszawie (1945-1956), Warszawa 2020.

Sawicki Karol, Stos ofiarny, Rzym 1976.

Siwiak Anna, Siwiak Wojciech, Zabudowania jezuickie w najnowszych badaniach archeologicznych, w: Jezuici w Bydgoszczy i okolicy, red. M. Puziak, Bydgoszcz 2018, s. $187-217$.

\section{Netografia}

https://diecezja.pl/aktualnosci/ks-wladyslaw-gurgacz-spoczal-na-cmentarzu-rakowickim -w-krakowie/ (dostęp: 01.12.2021). 
https://ipn.gov.pl/pl/aktualnosci/75628,Pozegnalismy-o-Jacka-Pleskaczynskiego.html (dostęp: 01.12.2021).

https://jezuici.pl/2012/09/zmarl-o-czeslaw-kozlowski-sj/ (dostęp: 01.12.2021).

https://jezuici.pl/2018/09/zmarl-o-stanislaw-pacholik-sj/ (dostęp: 01.12.2021).

https://jezuici.pl/2019/08/zmarl-o-jacek-pleskaczynski-sj/ (dostęp: 01.12.2021).

https://jezuici.pl/2019/09/zmarl-w-warszawie-o-hubert-czuma-sj/ (dostęp: 01.12.2021).

https://jezuici.pl/2019/10/zmarl-o-florian-pelka-sj/ (dostęp: 01.12.2021).

https://jezuici.pl/2019/12/zidentyfikowano-szczatki-o-wladyslawa-gurgacza-sj (dostęp: 01.12.2021).

Sprawozdanie Dyrekcji Zakładu Naukowo-Wychowawczego OO. Jezuitów w Bąkowicach pod Chyrowem za rok szkolny 1936/37, Przemyśl 1937, https://www.pbc.rzeszow.pl/ dlibra/publication/292/edition/256/content?ref=desc (dostęp: 01.12.2021).

Vilniaus jèzuitų gimnazija (vjg.lt) (dostęp: 02.12.2021).

\title{
JESUITS IN THE CAMERA. THE PHOTOGRAPHIC COLLECTION OF THE ARCHIVE OF GREATER POLAND AND MASOVIA PROVINCE OF THE SOCIETY OF JESUS
}

\begin{abstract}
The goal of the paper is to present photographic collection belonging to the Archive of Greater Poland and Masovia Province of the Society of Jesus. In recent years an increased interest in photographs can be observed among both professional historians and history enthusiasts alike. The Archive's photographs document period from the beginning of $20^{\text {th }}$ century to current day. First and foremost the present people: Jesuits of all levels of the Order's hierarchy, important historical figures of Poland and the Catholic Church and lay people connected to Jesuits. Second group of photographs is the pictures of buildings belonging to Jesuits and their institutions and works, then documentary photographs of important events in Polish history. The paper concludes with presentation of photographs made by Jesuits-enthusiasts of photography.
\end{abstract}

Keywords: polish Jesuits; Greater Poland and Masovia Province of the Society of Jesus; archival photography 